International Journal of Agricultural Science and Research (IJASR)

ISSN (P): 2250-0057; ISSN (E): 2321-0087

Vol. 10, Issue 1, Feb 2021, 31-40

(C) TJPRC Pvt. Ltd.

\title{
CONSUMER ATTITUDE TOWARDS EWOM COMMUNICATION ACROSS DIGITAL CHANNELS
}

\section{A. STUWART ANTON ${ }^{1}$, V. M. INDUMATHI ${ }^{2} \&$ S. GURUNATHAN ${ }^{3}$}

${ }^{I} P G$ Scholar, Department of Agricultural and Rural Management, Tamil Nadu Agricultural University, Coimbatore, India

\author{
${ }^{2}$ Assistant Professor (ARM), ICAR - KVK, Vamban, Pudukkottai, India
}

${ }^{3}$ Assistant Professor (Agrl. Economics), ICAR - KVK, Santhiyur, Salem, India

\section{ABSTRACT}

Electronic word of mouth (eWOM) is an important communication tool. Few studies have identified that consumer attitude towards electronic word of mouth varies across digital channels. The understanding of digital channels and eWOM communication helps companies to become more customer-centric. The objective was to develop a better understanding of consumer attitude towards $\mathrm{eWOM}$ digital channels and find the preferred digital channel with favourable attitude. The relationship between attitude and its antecedents in eWOM digital channels were analysed using correlation analysis. In addition, the significance of the relationship was analysed using chi square test. Research findings revealed that consumer attitude varies across digital channels. Social Media and Retail websites received favourable attitude and preferred by respondents. Blogs received low attitude for eWOM communications. Research suggests that forums are more effective to enhance message credibility. Social media can be used to create informative and entertaining campaigns, and to enhance brand attitude. The managerial implication and suggestions were provided for practitioners.

KEYWORDS: Electronic word of mouth (eWOM), Attitudes, Word of mouse, Digital channels, online word of mouth

Received: Dec 21, 2020; Accepted: Jan 11, 2021; Published: Jan 25, 2021; Paper Id.: IJASRFEB20214

\section{INTRODUCTION}

Electronic word of mouth (eWOM) is a persuasive and effective tool for building brand awareness, creating hype in the market. It also influences purchase decisions and loyalty (Arif, 2019). Consumers consider electronic word of mouth (eWOM) as one of the most useful information sources because it consists of opinion, experiences, and advice from past consumers (Mazzarol et al., 2007; Munnukka et al., 2015). Electronic word of mouth (eWOM) is defined as "eWOM is the dynamic and ongoing information exchange process between potential, actual, or former consumers regarding a product, service, brand, or company, which is available to a multitude of people and institutions via the Internet" (Ismagilova et al., 2017). The features of electronic word of mouth (eWOM) are speed, reach, convenience, and lack of face-to-face communication. Electronic word of mouth (eWOM) is also an important source of consumer expectation (Edwards et al., 2009). Most of eWOM communication takes place between strangers beyond geographical limitations, which are weak ties. While traditional word of mouth takes place between relatives, friends, which are strong ties (King et al., 2014).

Due to the development of the internet and technology, new ways of communication are developed for people to connect (Goyette et al., 2010). The newly developed communication channels are blogs, email, online forums, recommendation sites, online comment boards, digital virtual world, social networking sites, shopping websites etc. 
(Brown et al., 2007; Hennig-Thurau et al., 2010; Li \& Zhan, 2011; Libai et al., 2010). Electronic word of mouth (eWOM) spreads through different platforms such as email, instant messaging, forums, review sites, online communities, blogs, etc. and the context is computer-mediated and complex (Dwyer et al., 2007; King et al., 2014).

$\mathrm{Hu}$ and $\mathrm{Ha}$ (2015) categorized electronic word of mouth (eWOM) as four classes namely Specialized eWOM, Social eWOM, Affiliated eWOM, and Miscellaneous eWOM. Specialized eWOM refers to the customers' reviews or comments that are posted on rating websites but there is no selling of products on rating websites. The examples of specialized eWOM websites are Epinions, Mouthshut, and Yelp etc. Social eWOM refers to comments, reviews, or information about a product/brand on Social media. Examples of social eWOM are Facebook, Twitter, and LinkedIn etc. Miscellaneous eWOM includes platforms such as blogs, forums, discussion boards where information about a product/brand is exchanged. With all these technologies, we can be more customer-centric. To become more customercentric, it is important to learn whether the consumer attitude varies across different digital channels. The two objectives were to find the preferred digital channel of consumers for eWOM communication and to understand the relationship between the consumer attitude and its antecedents across eWOM digital channels.

\section{LITERATURE REVIEW}

eWOM is "the knowledge exchange that consumers carry out online" (Wu \& Wang, 2011). Hennig-Thurau et al. (2004) defined eWOM as "any positive or negative statement made by potential, actual, or former customers about a product or company, which is made available to a multitude of people and institutions via the Internet”. Chatterjee (2001) defined "eWOM is a type of communication which can take the form of reviews such as user comments, ratings, numerical scale evaluations, or videos".

e-WOM is one of the most effective factors influencing brand image and purchase intention of brands in consumer markets (Jalilvand \& Samiei, 2012). Consumer reviews have an impact on the decision-making of consumers(S. H. Kim et al., 2013). Consumers read and rely on consumer reviews (Chevalier \& Mayzlin, 2006). Customers use electronic word of mouth for the reduction of the potential hazards when decision making before buying products (Hussain et al., 2017). It has the potential to impact perceptions or actions (Sweeney et al., 2008).

eWOM on Digital Channel helps to reduce risk in a purchase, and prevent bad experience (Khammash \& Griffiths, 2011). Digital channels have different features and different appeals that influence consumer attitudes towards electronic word of mouth communication (Gvili \& Levy, 2016). Digital channels have different characteristics. Social Networks and online communities are used to share information (Cheung et al., 2008). Chat and text messages are intimate and immediate. Some channels such as online comment boards have members remain anonymous. Some channels such as forums have credibility by acknowledging the source (Steffes \& Burgee, 2009). Kudeshia and Kumar (2017) found that social electronic word of mouth generated through social media websites affect and have influence on brand attitude and purchase intention.

\subsection{Attitude Towards eWOM Communication}

Attitude is a significant positive predictor of consumer's Web advertising behaviour and purchase intention (Saadeghvaziri et al., 2013). Perloff (2020) defined attitude, as "Attitude is a very complex, hypothetical construct. It is a state of mind that can be changed by persuasion but only be inferred by observing people's responses elicited by stimuli”. Attitude towards electronic word of mouth is considered as a significant antecedent to understand people's response to the messages (Gvili 
\& Levy, 2016).

Ducoffe (1996) and Brackett and Carr (2001) provided informativeness, irritation, value, entertainment, and credibility as antecedents of attitude. Research found that argument quality, source credibility, source attractiveness, source perception, and source style has influences on social media users' attitudes and intentions (Teng et al., 2017). A study shown that the attitude of consumers towards eWOM varies across digital channels (Gvili \& Levy, 2016).

Informativeness in advertising means that consumers are informed about product alternatives and help them make informed decisions (Ducoffe, 1996). Informativeness refers to the presence of informational content in advertising messages. Digital message Informativeness is positively related to advertising value (Dix et al., 2012; Y. J. Kim \& Han, 2014; Van-Tien Dao et al., 2014) and attitude towards the advertisement (Goodrich et al., 2015). Informativeness means that the digital channels have good and relevant product information. It is provided on time (Gvili \& Levy, 2016).

Entertainment digital messages reduce intrusiveness and increase positive attitude towards message and platform (Chang et al., 2013). Entertainment is the ability of eWOM messages to provide escapism, emotional release, and diversion (Ducoffe, 1996; McQuail, 1987). Entertainment and informativeness are two properties of electronic word of mouth messages that can characterize consumer behaviour online (Babin et al., 1994; Cotte et al., 2006). In digital communications, the perceived value of the message correlates with both entertainment and informativeness (Dix et al., 2012; Van-Tien Dao et al., 2014). Research study suggests that individuals share or forward messages or content that they find to be entertaining and fun (Kaplan \& Haenlein, 2010).

Irritation is the ability of the eWOM message to cause insult, annoyance, or offense (Ducoffe, 1996). Irritation leads to message scepticism and avoidance of digital messages (Baek \& Morimoto, 2012). From the perspective of the receiver, the speed and ease of eWOM message creation may lead to annoyance and clutter (Hennig-Thurau et al., 2004). Irritation tends to annoy and insults people's intelligence. Irritating messages has a positive influence on Consumer attitude toward the channel (Gvili \& Levy, 2016).

Value is the subjective evaluation of consumers based on the utility or worth of the received eWOM messages (Ducoffe, 1995). Studies suggest that the value of eWOM messages is the outcome of irritation, entertainment, credibility, and informativeness (Van-Tien Dao et al., 2014). It also affects attitude towards message positively (Brackett \& Carr, 2001). Value shows usefulness and importance of eWOM messages (Gvili \& Levy, 2016).

The credibility of electronic word of mouth messages is the consumers' perception towards recommendations, reviews or, comments as to believe it or not (Nabi \& Hendriks, 2003). It improves value and attitude (Clarkson et al., 2008). It is also a key determinant of eWOM adoption (Fan \& Miao, 2012). Credibility involves trustworthiness and believability of eWOM messages(Gvili \& Levy, 2016). Credibility is a mediator of message value. Credibility affects consumer attitude toward eWOM messages in social networking sites (Gvili \& Levy, 2018).

\section{METHODOLOGY}

\section{Sampling and Data Collection}

Data were collected through an interview schedule. Participants were selected using non-probability sampling (Convenience Sampling). The study area for research purpose was Coimbatore City. One hundred and fifty responses were interviewed for the study. The participants were informed that the study was voluntary and information provided will be 
used only for academic purposes.

The eWOM digital platforms selected for the study were Email, Forum, Social Media, SMS, Blog, Rating Websites, and Retail Sites. These are the seven major eWOM major communication channels (Gvili \& Levy, 2016; Hu \& Ha, 2015). Attitude towards eWOM communication consists of five antecedents. The antecedents were entertainment, informativeness, irritation, value, and credibility (Brackett \& Carr, 2001; Ducoffe, 1996). The antecedents and general attitude towards seven major eWOM communication channels were collected from respondents.

All the items were measured using the multiple response questions. Respondents were asked to select platforms for items such as attitude, entertainment, informativeness, irritation, value, and credibility. Frequency analysis, Pearson Chi square test (test the level of significance), and phi coefficient correlation (level of dependence) were conducted using SPSS. Rea and Parker (1992) classified the Phi correlation as follows: $00 \&$ under 0.10 is Negligible, $0.10 \&$ under 0.20 is weak, $0.20 \&$ under 0.40 is moderate, $0.40 \&$ under 0.60 is relatively strong, $0.60 \&$ under 0.80 is strong, and 0.80 and 1 is very strong.

\section{RESULTS}

The Frequency analysis was conducted to understand the demographic profile of the respondents. Majority of the respondents were male (59.3 per cent) and majority of the respondents age ranged between 18 and 25 years (44.7 per cent). About 25.3 per cent of respondents earned monthly income between Rs. 30,001 - Rs. 40,000. Majority of the respondents (63.3 per cent) were graduates. Overall, the participants were younger and well educated (Table 1)

Table 1: Demographic Profile of respondents

\begin{tabular}{|c|c|c|c|}
\hline Demographics & Categories & Frequency & Percentage \\
\hline \multirow{2}{*}{ Gender } & Female & 61 & 40.7 \\
\hline & Male & 89 & 59.3 \\
\hline \multirow{5}{*}{ Age } & $18-25$ & 66 & 44.7 \\
\hline & $26-35$ & 31 & 20.7 \\
\hline & $36-45$ & 19 & 12.7 \\
\hline & $46-55$ & 21 & 14 \\
\hline & Above 55 & 12 & 8 \\
\hline \multirow{7}{*}{ Income per month } & Below Rs. 10,000 & 6 & 4 \\
\hline & Rs. $10,001-20,000$ & 7 & 4.7 \\
\hline & Rs. $20,001-30,000$ & 31 & 20.7 \\
\hline & Rs. $30,001-40,000$ & 38 & 25.3 \\
\hline & Rs. 40,001 - 50,000 & 20 & 13.3 \\
\hline & Above Rs. 50,000 & 33 & 22 \\
\hline & No Income & 15 & 10 \\
\hline \multirow{2}{*}{ Education } & Diploma & 3 & 2 \\
\hline & High School & 2 & 1.3 \\
\hline
\end{tabular}




\begin{tabular}{|l|l|l|l|} 
& Undergraduate & 95 & 63.3 \\
\cline { 2 - 4 } & Postgraduate & 50 & 33.3 \\
\hline
\end{tabular}

\section{Consumer Attitude across eWOM digital channels}

Table 2 summarizes the attitude towards eWOM messages across digital channels. Majority of the respondents had a favourable attitude towards eWOM messages on social media platforms (59 per cent) and retail websites (59 per cent). Blogs (14 per cent) and Forum (17 per cent) were low in attitude towards eWOM messages. eWOM messages received through Blogs (47 per cent), Rating websites (47 per cent), and Social media (44 per cent) were found to be informative. SMS (29 per cent) scored low on informativeness of eWOM messages. Majority of the respondents found eWOM messages received through the Retail website (46 per cent) and Rating websites (41 per cent) were valuable. SMS (19 per cent) got low on value. Retail website (38 per cent) scored high on eWOM message credibility. SMS (8 per cent), Social media (12 per cent), forum (14 per cent), and Blogs (15 per cent) scored low on credibility.

Majority of the respondents (61 per cent) found social media entertaining. Retail Website ( 9 per cent), SMS (6 per cent), and Rating sites (11 per cent) are low on entertainment. Most of the Respondents (49 per cent) felt irritated by eWOM messages received through SMS. Respondents felt less irritated by Rating websites (17 per cent), Retail websites (17 per cent), and Blogs (17 per cent). Based on Table 2, it was observed that the consumer attitude varied across different eWOM digital channels. The features and form of digital channels changed the consumer attitude towards eWOM messages.

Table 2: Consumer Attitude across eWOM digital channels

\begin{tabular}{|c|c|c|c|c|c|c|c|c|c|c|c|c|}
\hline \multirow{2}{*}{$\begin{array}{l}\text { Digital eWOM } \\
\text { channels }\end{array}$} & \multicolumn{2}{|c|}{ Attitude } & \multicolumn{2}{|c|}{ Informativeness } & \multicolumn{2}{|c|}{ Value } & \multicolumn{2}{|c|}{ Credibility } & \multicolumn{2}{|c|}{ Entertainment } & \multicolumn{2}{|c|}{ Irritation } \\
\hline & $\mathbf{n}$ & $\begin{array}{l}\text { per } \\
\text { cen } \\
t\end{array}$ & $\mathbf{n}$ & per cent & $\mathbf{n}$ & $\begin{array}{l}\text { pe } \\
\text { r } \\
\text { ce } \\
\text { nt }\end{array}$ & $\mathbf{n}$ & $\begin{array}{l}\text { per } \\
\text { cent }\end{array}$ & $\mathbf{n}$ & per cent & $\mathbf{n}$ & $\begin{array}{l}\text { per } \\
\text { cent }\end{array}$ \\
\hline Social Media & 89 & 59 & 66 & 44 & 36 & 24 & 18 & 12 & 92 & 61 & 35 & 23 \\
\hline Rating Website & 33 & 22 & 70 & 47 & 61 & 41 & 33 & 22 & 16 & 11 & 26 & 17 \\
\hline Retail Website & 89 & 59 & 58 & 39 & 69 & 46 & 57 & 38 & 13 & 9 & 25 & 17 \\
\hline Forum & 26 & 17 & 62 & 41 & 46 & 31 & 21 & 14 & 19 & 13 & 29 & 19 \\
\hline Blogs & 21 & 14 & 70 & 47 & 39 & 26 & 22 & 15 & 29 & 19 & 25 & 17 \\
\hline Email & 56 & 37 & 59 & 39 & 40 & 27 & 28 & 19 & 27 & 18 & 48 & 32 \\
\hline SMS & 42 & 28 & 44 & 29 & 28 & 19 & 12 & 8 & 9 & 6 & 73 & 49 \\
\hline
\end{tabular}

Note: Multiple response table, $\mathrm{n}=150 ; \mathrm{n}$ - Frequency and per cent - Percentage

\section{Relationship between eWOM platforms attitude and its antecedents}

Table 3 summarizes the relationship observed between eWOM platforms attitude and its antecedents. It provides the degree of dependence and test of significance to understand the relationship. In Social Media, Informativeness $(\varphi=0.242)$ and Entertainment ( $\varphi=0.207)$ had a moderate positive relationship and significant impact on consumer attitude. Value in Social media had a significant and weak positive relationship $(\varphi=0.179)$ with consumer attitude. 
In the case of rating websites, Informativeness had a significant impact and a weak positive relationship $(\varphi=$ $0.181)$ with consumer attitude. Value was also found to have a significant and moderate positive relationship $(\varphi=0.248)$ with consumer attitude. Credibility was also found to have a significant impact and a moderate positive relationship $(\varphi=$ 0.262) on consumer attitude towards rating websites. In review websites, Credibility had a significant impact and a moderate positive relationship $(\varphi=0.201)$ with consumer attitude. Value was also found to have a significant and moderate positive relationship $(\varphi=0.274)$ with consumer attitude.

The test results observed were insignificant in email. Attitude and its antecedents do not have evidence to suggest a relationship in the case of email. In Forum, credibility was found to have a weak positive relationship $(\varphi=0.171)$ with consumer attitude. The other antecedents were insignificant. The results showed that informativeness $(\varphi=0.162)$ and value $(\varphi=0.286)$ had a moderate positive and significant impact on the consumer attitude in Blogs.

In SMS, it was evident that informativeness $(\varphi=0.25)$ and value $(\varphi=0.273)$ had a significant and moderate positive relationship with attitude. It was observed that the relationship between attitude and its antecedents varies depending on the digital eWOM channels.

Table 3: Phi Correlation Analysis and test of significance (Pearson chi square test)

\begin{tabular}{|l|l|l|l|l|l|l|l|}
\hline \multicolumn{1}{|c|}{$\begin{array}{c}\text { Phi Correlation } \\
\text { Coefficient }\end{array}$} & $\begin{array}{c}\text { Social } \\
\text { Media }\end{array}$ & $\begin{array}{c}\text { Rating } \\
\text { Websites }\end{array}$ & $\begin{array}{c}\text { Retail } \\
\text { Websites }\end{array}$ & \multicolumn{1}{|c|}{ Email } & Forum & Blogs & SMS \\
\hline Attitude - Informative & $0.242^{* *}$ & $0.181^{*}$ & 0.1 & 0.169 & 0.045 & $0.162^{*}$ & $0.25^{* *}$ \\
\hline Attitude - Entertainment & $0.207^{*}$ & 0.077 & 0.083 & 0.141 & 0.016 & 0.003 & 0.093 \\
\hline Attitude - Credibility & 0.139 & $0.262^{* *}$ & $0.201 *$ & 0.019 & $0.171^{*}$ & 0.05 & 0.035 \\
\hline Attitude - Value & $0.179^{*}$ & $0.248^{* *}$ & $0.274 * *$ & 0.189 & 0.039 & $0.286^{* *}$ & $0.273^{* *}$ \\
\hline Attitude - Irritation & 0.121 & 0.012 & 0.03 & 0.116 & 0.046 & 0.129 & 0.102 \\
\hline Note: p-value of chi square test; ${ }^{*} \mathrm{p}<0.05 ; * \mathrm{p}<0.01$ \\
\hline
\end{tabular}

\section{CONCLUSIONS}

The result showed that consumers preferred social media platforms and retail websites. These digital platforms scored high on consumer attitude. The other channels such as Blogs and Forum suffered from low consumer attitude. The differences in digital channels influence consumer attitudes. Users who seek advice from the experts usually visit the forum. The users are usually goal-oriented and the members of the forum are subject matter experts of a particular interest (Shih et al., 2015). Forum is perceived as less irritating and entertaining channels (Gvili \& Levy, 2016). The result from the correlation analysis showed that forum was found to be credible digital channels. The credibility is due to the professional and experts who act as moderators of the forum (Gvili \& Levy, 2016).

Social Media platforms allow users to share information (Kaplan \& Haenlein, 2010). The results showed that social media was informative, entertaining, and valuable. It is due to the anonymous users who create a rich source of rapid information (Erkan \& Evans, 2018). Entertainment creates a positive environment and experience for consumers (Schulze et al., 2014). Social media is also perceived as a high-value digital platform (Gvili \& Levy, 2016).

SMS is used to communicate short and instant messages. The result found that consumer attitude was low in SMS which explains the low credibility. Nevertheless, it was found to be useful and informative. On the other hand, blogs include detailed and refined messages. It was also found to be valuable and informative. However, people consider blogs less 
credible while receiving product information.

Consumer reviews from retail or shopping website are anonymous and shown to have detailed information. The eWOM messages on shopping websites or retail websites are more influential on online purchase intention (Erkan \& Evans, 2018). The result showed that retail sites were informative, credible, and valuable. Research suggested that shopping websites were more influential than social media due to their informativeness, usefulness, and credibility. Rating websites have reviews of products provided by the platform's users and consumers. It is a specialized eWOM and the channel does not involve in product selling. Results suggested that rating websites were informative, credible, and useful.

\section{MANAGERIAL IMPLICATIONS}

Marketers should adjust their strategy according to their marketing objectives. The strategy should also be adjusted to the digital channel. Marketers can improve consumers' attitudes towards their brand by focusing on message delivery through social media. To reach consumers with informative and timely messages, SMS and Social Media can be used. When the credibility or trustworthiness of messages are concerned, marketers can use forums.

Marketers who seek to develop entertainment campaigns can make use of social media, which was found to be highly informative and entertaining. It is also best to select digital platforms that are valuable and found credible by target consumers. Engagement through digital channels tends to improve brand relationship. The marketers in their websites can use the positive eWOM shared by the consumers. This is known as testimonial advertising. Testimonial advertising is also found to more persuasive and effective in eWOM communication (Bickart \& Schindler, 2001).

The eWOM messages that are generated online can be used for data analysis to gain insights and understand consumer behaviour. The marketers to understand eWOM messages can use sentiment analysis, topic modelling, and content analysis etc. Marketers can also make use of web care. Web care is, "the act of engaging in online interactions with (complaining) consumers, by actively searching the web to address consumer feedback (e.g., questions, concerns and complaints)" (Van Noort \& Willemsen, 2012). Web care is helpful in positively influencing consumers with exposure to negative reviews (Van Noort \& Willemsen, 2012).

\section{Limitations and Further Research}

The study was conducted under the notion that eWOM communication varies across digital channels. The intensity of usage and expectation of users may vary across different eWOM channels. Other new digital channels and applications can be studied and understand the impact on consumers attitudes. The impact of eWOM digital channels can be studied across different product categories. The impact of eWOM digital channels on actual sales can help in building good media strategies.

\section{REFERENCES}

1. Arif, M. E. (2019). The Influence Of Electronic Word Of Mouth (Ewom), Brand Image, And Price On Re-Purchase Intention Of Airline Customers. Jurnal Aplikasi Manajemen, 17(2), 345-356.

2. Babin, B. J., Darden, W. R., \& Griffin, M. (1994). Work and/or fun: measuring hedonic and utilitarian shopping value. Journal of consumer research, 20(4), 644-656.

3. Baek, T. H., \& Morimoto, M. (2012). Stay away from me. Journal of advertising, 41(1), 59-76. 
4. Bickart, B., \& Schindler, R. M. (2001). Internet forums as influential sources of consumer information. Journal of interactive marketing, 15(3), 31-40.

5. Brackett, L. K., \& Carr, B. N. (2001). Cyberspace advertising vs. other media: Consumer vs. mature student attitudes. Journal of Advertising Research, 41(5), 23-32.

6. Brown, J., Broderick, A. J., \& Lee, N. (2007). Word of mouth communication within online communities: Conceptualizing the online social network. Journal of interactive marketing, 21(3), 2-20.

7. Chang, H. H., Rizal, H., \& Amin, H. (2013). The determinants of consumer behaviour towards email advertisement. Internet Research.

8. Chatterjee, P. (2001). Online reviews: do consumers use them?

9. Cheung, C. M., Lee, M. K., \& Rabjohn, N. (2008). The impact of electronic word-of-mouth: The adoption of online opinions in online customer communities. Internet Research: Electronic Networking Applications and Policy, 18(3), 229-247.

10. Chevalier, J. A., \& Mayzlin, D. (2006). The effect of word of mouth on sales: Online book reviews. Journal of marketing research, 43(3), 345-354.

11. Clarkson, J. J., Tormala, Z. L., \& Rucker, D. D. (2008). A new look at the consequences of attitude certainty: The amplification hypothesis. Journal of Personality and Social Psychology, 95(4), 810.

12. Cotte, J., Chowdhury, T. G., Ratneshwar, S., \& Ricci, L. M. (2006). Pleasure or utility? Time planning style and web usage behaviors. Journal of interactive marketing, 20(1), 45-57.

13. Dix, S., Ferguson, G., Logan, K., Bright, L. F., \& Gangadharbatla, H. (2012). Facebook versus television: advertising value perceptions among females. Journal of Research in Interactive Marketing.

14. Ducoffe, R. H. (1995). How consumers assess the value of advertising. Journal of Current Issues \& Research in Advertising, 17(1), 1-18.

15. Ducoffe, R. H. (1996). Advertising value and advertising on the web. Journal of Advertising Research, 36(5), 21-21.

16. Dwyer, C., Hiltz, S., \& Passerini, K. (2007). Trust and privacy concern within social networking sites: A comparison of Facebook and MySpace. AMCIS 2007 proceedings, 339.

17. Edwards, A., Edwards, C., Shaver, C., \& Oaks, M. (2009). Computer-mediated word-of-mouth communication on ratemyprofessors. com: Expectancy effects on student cognitive and behavioral learning. Journal of Computer-Mediated Communication, 14(2), 368-392.

18. Erkan, I., \& Evans, C. (2018). Social media or shopping websites? The influence of eWOM on consumers' online purchase intentions. Journal of Marketing Communications, 24(6), 617-632.

19. Fan, Y.-W., \& Miao, Y.-F. (2012). Effect of electronic word-of-mouth on consumer purchase intention: The perspective of gender differences. International Journal of Electronic Business Management, 10(3), 175.

20. Goodrich, K., Schiller, S. Z., \& Galletta, D. (2015). Consumer reactions to intrusiveness of online-video advertisements: do length, informativeness, and humor help (or hinder) marketing outcomes? Journal of Advertising Research, 55(1), 37-50.

21. Goyette, I., Ricard, L., Bergeron, J., \& Marticotte, F. (2010). e-WOM Scale: word-of-mouth measurement scale for e-services context. Canadian Journal of Administrative Sciences/Revue Canadienne des Sciences de l'Administration, 27(1), 5-23.

22. Gvili, Y., \& Levy, S. (2016). Antecedents of attitudes toward eWOM communication: differences across channels. Internet Research. 
23. Gvili, Y., \& Levy, S. (2018). Consumer engagement with eWOM on social media: the role of social capital. Online Information Review.

24. Hennig-Thurau, T., Gwinner, K. P., Walsh, G., \& Gremler, D. D. (2004). Electronic word-of-mouth via consumer-opinion platforms: what motivates consumers to articulate themselves on the internet? Journal of interactive marketing, 18(1), 38-52.

25. Hennig-Thurau, T., Malthouse, E. C., Friege, C., Gensler, S., Lobschat, L., Rangaswamy, A., \& Skiera, B. (2010). The impact of new media on customer relationships. Journal of service research, 13(3), 311-330.

26. Hu, X., \& Ha, L. (2015). Which form of word-of-mouth is more important to online shoppers? A comparative study of WOM use between general population and college students. Journal of Communication and Media Research, 7(2), 15-35.

27. Hussain, S., Ahmed, W., Jafar, R. M. S., Rabnawaz, A., \& Jianzhou, Y. (2017). eWOM source credibility, perceived risk and food product customer's information adoption. Computers in Human Behavior, 66, 96-102.

28. Ismagilova, E., Dwivedi, Y. K., Slade, E., \& Williams, M. D. (2017). Electronic word of mouth (eWOM) in the marketing context: A state of the art analysis and future directions: Springer.

29. Jalilvand, M. R., \& Samiei, N. (2012). The effect of electronic word of mouth on brand image and purchase intention. Marketing Intelligence \& Planning.

30. Kaplan, A. M., \& Haenlein, M. (2010). Users of the world, unite! The challenges and opportunities of Social Media. Business horizons, 53(1), 59-68.

31. Khammash, M., \& Griffiths, G. H. (2011). 'Arrivederci CIAO. com, Buongiorno Bing. com'-Electronic word-of-mouth (eWOM), antecedences and consequences. International Journal of Information Management, 31(1), 82-87.

32. Kim, S. H., Park, N., \& Park, S. H. (2013). Exploring the effects of online word of mouth and expert reviews on theatrical movies' box office success. Journal of Media Economics, 26(2), 98-114.

33. Kim, Y. J., \& Han, J. (2014). Why smartphone advertising attracts customers: A model of Web advertising, flow, and personalization. Computers in Human Behavior, 33, 256-269.

34. King, R. A., Racherla, P., \& Bush, V. D. (2014). What we know and don't know about online word-of-mouth: A review and synthesis of the literature. Journal of interactive marketing, 28(3), 167-183.

35. Kudeshia, C., \& Kumar, A. (2017). Social eWOM: does it affect the brand attitude and purchase intention of brands? Management Research Review.

36. Li, J., \& Zhan, L. (2011). Online persuasion: How the written word drives WOM: Evidence from consumer-generated product reviews. Journal of Advertising Research, 51(1), 239-257.

37. Libai, B., Bolton, R., Bügel, M. S., De Ruyter, K., Götz, O., Risselada, H., \& Stephen, A. T. (2010). Customer-to-customer interactions: broadening the scope of word of mouth research. Journal of service research, 13(3), 267-282.

38. Mazzarol, T., Sweeney, J. C., \& Soutar, G. N. (2007). Conceptualizing word-of-mouth activity, triggers and conditions: an exploratory study. European Journal of Marketing.

39. McQuail, D. (1987). Mass communication theory: An introduction: Sage Publications, Inc.

40. Munnukka, J., Karjaluoto, H., \& Tikkanen, A. (2015). Are Facebook brand community members truly loyal to the brand? Computers in Human Behavior, 51, 429-439.

41. Nabi, R. L., \& Hendriks, A. (2003). The persuasive effect of host and audience reaction shots in television talk shows. Journal of Communication, 53(3), 527-543. 
42. Perloff, R. M. (2020). The dynamics of persuasion: Communication and attitudes in the twenty-first century: Routledge.

43. Rea, L. M., \& Parker, R. A. (1992). Designing and conducting survey research San Francisco. CA: Jossey-Boss.

44. Saadeghvaziri, F., Dehdashti, Z., \& Askarabad, M. R. K. (2013). Web advertising. Journal of Economic and Administrative Sciences.

45. Schulze, C., Schöler, L., \& Skiera, B. (2014). Not all fun and games: Viral marketing for utilitarian products. Journal of Marketing, 78(1), 1-19.

46. Shih, H.-p., Lai, K.-h., \& Cheng, T. E. (2015). Examining structural, perceptual, and attitudinal influences on the quality of information sharing in collaborative technology use. Information Systems Frontiers, 17(2), 455-470.

47. Steffes, E. M., \& Burgee, L. E. (2009). Social ties and online word of mouth. Internet Research.

48. Sweeney, J. C., Soutar, G. N., \& Mazzarol, T. (2008). Factors influencing word of mouth effectiveness: receiver perspectives. European Journal of Marketing.

49. Teng, S., Khong, K. W., Chong, A. Y. L., \& Lin, B. (2017). Persuasive electronic word-of-mouth messages in social media. Journal of Computer Information Systems, 57(1), 76-88.

50. Van-Tien Dao, W., Nhat Hanh Le, A., Ming-Sung Cheng, J., \& Chao Chen, D. (2014). Social media advertising value: The case of transitional economies in Southeast Asia. International Journal of Advertising, 33(2), 271-294.

51. Van Noort, G., \& Willemsen, L. M. (2012). Online damage control: The effects of proactive versus reactive webcare interventions in consumer-generated and brand-generated platforms. Journal of interactive marketing, 26(3), 131-140.

52. Wu, P. C., \& Wang, Y. C. (2011). The influences of electronic word-of-mouth message appeal and message source credibility on brand attitude. Asia Pacific Journal of Marketing and Logistics. 